JARES, Vol. 4 No. 1 March, 2019; p-ISSN: 2502-826X; e-ISSN: 2503-1163

Copyrights@Balitar Islamic University, Blitar, Indonesia;

https://ejournal.unisbablitar.ac.id/index.php/jares

Citation: Azzari Aldaf , H., Hartami Santi , I., \& Primasari, Y. (2019). DESIGN OF

TANDON AND AUTOMATIC FILLING TOOLS ON DISPENSERS WITH

ULTRASONIC SENSORS. JARES (Journal of Academic Research and Sciences), 4(1), 55-64. https://doi.org/10.30957/jares.v4i1.690

\title{
DESIGN OF TANDON AND AUTOMATIC FILLING TOOLS ON DISPENSERS WITH ULTRASONIC SENSORS
}

\author{
Indyah Hartami Santi ${ }^{1}$ Yusniarsi Primasari ${ }^{2}$ Hafizt Azzari Aldaf ${ }^{3}$ \\ Information Technology Faculty, Islamic University of Balitar \\ e-mail: indyahartamisanti@gmail.com, yusniarsi2015@gmail.com,
}

hafistazzari@gmail.com,

\begin{abstract}
Nowdays, The development of water dispensers has hot and cold water technology, but fills water into cold and hot water storage tanks by lifting and putting the gallons on top of the dispenser so that water can flow into hot and cold water storage tanks, this is assessed less efficient. The purpose of making this tool is to make it easier for users to install gallons without having to lift the gallon and put it on top of the reservoir, it can also facilitate the taking of drinking water without having to press or open the faucet first. Because in modern era, the need for tools that work automatically and efficiently are increasing. The results of this study indicate that automatic water and faucet filler devices in dispensers using ultrasonic sensors as a whole work well and are in accordance with the function specified. The function of the ultrasonic sensor is as a reader the maximum limit of water level in the reservoir, so that when the water is in its maximum state, the pump will stop filling the reservoir. And the ultrasonic sensor in front of the dispenser functions to read the glass, the sensor will detect and then be received by the microcontroller and continue to execute the relay and open the selenoid so that the water can come out.
\end{abstract}

\section{Keywords: Dispensers, Mikrokontroler Arduino Uno, Ultrasonic Sensors.}

\section{INTRODUCTION}

Dispenser is a device used to store drinking water, replacing the function of similar household appliances that already existed namely teapots, kettles, or thermos, but as a development of ordinary water storage devices dispensers have many advantages including large capacity to bias keep water supplies in a large capacity, besides that there are also dispensers that have features that can make water become hot or cold, so that when you need hot water or cold water no longer have to cook or put it into the refrigerator. Generally the hot water produced reaches a temperature of 85 degrees Celsius and the cold water produced can reach a temperature of 15 degrees Celsius. (Early, 2015).

The development of water dispensers currently has hot and cold water technology, but fills water into cold and hot water storage tanks by lifting and putting the gallons on top of the dispenser so that water can flow into hot and cold water storage tanks, this is considered less efficient, because we still have to spend energy to lift the gallon on top of the dispenser, the use of a dispenser with a manual faucet is also considered to be less efficient because when the human water collection process still 
JARES, Vol. 4 No. 1 March, 2019; p-ISSN: 2502-826X; e-ISSN: 2503-1163

Copyrights@ Balitar Islamic University, Blitar, Indonesia;

https://ejournal.unisbablitar.ac.id/index.php/jares

Citation: Azzari Aldaf , H., Hartami Santi , I., \& Primasari, Y. (2019). DESIGN OF

TANDON AND AUTOMATIC FILLING TOOLS ON DISPENSERS WITH

ULTRASONIC SENSORS. JARES (Journal of Academic Research and Sciences), 4(1), 55-64. https://doi.org/10.30957/jares.v4i1.690

has to be demanded, the power presses the faucet to release water.

This problem can be overcome by changing the position of the gallon that previously existed above to below, by adding an automatic water reservoir filling device to the dispenser using an ultrasonic sensor, the ultrasonic sensor itself is a sensor that serves to convert physical quantities (sounds) to electrical quantities and vice versa. The workings of this sensor are based on the principle of reflection of a sound wave (ultrasonic sound) so that it can be used to interpret the existence (distance) of an object with a certain frequency. Later the ultrasonic sensor will be distributed to the container and water pump. The workings of this ultrasonic sensor by controlling the water level in the reservoir, when the water in the reservoir at the maximum level of the sensor will read and the water that fills into the reservoir will stop. Filling the reservoir in this dispenser is done automatically, when water is taken, the water reservoir will be fill, this is intended to keep the water in the reservoir not running out. The design of the faucet for taking water in this dispenser also uses an ultrasonic sensor, this ultrasonic sensor will be installed near the output as a glass reader sensor so that when the glass is brought close to the ultrasonic sensor, the sensor will respond to objects and the water in the dispenser will come out, and when the glass is kept away from the sensor the faucet will close so that the water will stop coming out

Research conducted by previous researchers included tandon water fillers and automatic faucets in dispensers using this ultrasonic sensor, such as research conducted by: Dwisnita Kusbintarti (2014), Imran Oktariawan, Martinusdan Sugiyanto (2014), Gusrizam Danel, Wildian ( 2012), Elektrokontrol (2011), Gamis Pindhika Darma, Wisnu Wendanto (2015), Subandi (2014), Adhitya, V. N, Hafidudin. Sarwoko, M. (2014).

Ultrasonic sensors are sounds or vibrations with high frequency to be heard by human ears, which is above 20 kilos Hertz. Only some animals, such as dolphins, use them for communication, while bats use ultrasonic waves for navigation. Ultrasonic waves can propagate on solid media, liquid and gas. Ultrasonic sensors function to convert physical quantities (sounds) into electrical quantities and vice versa. A sensor is a device that converts a value (signal / energy) physically to another physical value into an analog unit so that it can be read by an electronic circuit.

Water pump is a device used to move fluids (fluid) from one place to another, through the media pipe (channel) by adding energy to the fluid being moved and continues continuously. The pump operates with the principle of making a pressure difference between the suction parts (suction) and discharge. The difference in pressure is generated from a 
JARES, Vol. 4 No. 1 March, 2019; p-ISSN: 2502-826X; e-ISSN: 2503-1163

Copyrights@ Balitar Islamic University, Blitar, Indonesia;

https://ejournal.unisbablitar.ac.id/index.php/jares

Citation: Azzari Aldaf , H., Hartami Santi , I., \& Primasari, Y. (2019). DESIGN OF

TANDON AND AUTOMATIC FILLING TOOLS ON DISPENSERS WITH

ULTRASONIC SENSORS. JARES (Journal of Academic Research and Sciences), 4(1), 55-64. https://doi.org/10.30957/jares.v4i1.690

mechanism such as a spinning wheel impeller that makes the state of the suction side is almost vacuum. This pressure difference sucks up the liquid so that it can move from one reservoir to another.

Selenoid valve is a valve that is driven by electrical energy through a solenoid, has a coil as a drive that serves to drive the piston that can be driven by $A C$ or DC currents, pneumatic solenoid valve or valve (solenoid valve) has an output hole, input hole and exhaust holes. The input hole, serves as a terminal/ place of pressurized air entering or supply (service unit), while the output hole functions as a terminal or where outgoing wind pressure is connected to pneumatic, and exhaust holes, serves as a channel to release compressed air trapped when the plunger moves or move position when the pneumatic solenoid valve works. Solenoid valve will work if the coil / coil get an electric current voltage that matches the working voltage (most solenoid valve working voltages are 100/200VAC and most working voltage at DC voltage is $12 / 24 \mathrm{VDC})$. And a pin will be attracted because of the magnetic force produced from the selenoid coil. And when the pin is pulled up, the fluid will flow from room $C$ to section $D$ quickly. So that the pressure in room $\mathrm{C}$ drops and the incoming fluid pressure lifts the diaphragm. So that the main valve is open and the fluid flows directly from $A$ to $F$.

Arduino uno is an Atmega328 based microcontroller board that has 14 input pins from digital output where 6 analog input pins, $16 \mathrm{MHz}$ crystal oscillator, usb connection, power jack, ICSP header, and reset button. Arduino Uno contains everything needed to support a microcontroller. To support the microcontroller so that it can be used, it is enough to simply connect the Arduino Uno board to the computer using a USB cannon or electricity with $A C$ to the DC adapter or battery to run it. This document is a template for the Word (doc) version.

\section{RESEARCH METHODS}

\subsection{Analysis of Tool Requirements}

The stages of tool requirements analysis describe the details of the components used for water tandon fillers and automatic faucets in dispensers. The names of the tool components and types can be seen as in following table 1: 
JARES, Vol. 4 No. 1 March, 2019; p-ISSN: 2502-826X; e-ISSN: 2503-1163

Copyrights@ Balitar Islamic University, Blitar, Indonesia;

https://ejournal.unisbablitar.ac.id/index.php/jares

Citation: Azzari Aldaf , H., Hartami Santi , I., \& Primasari, Y. (2019). DESIGN OF

TANDON AND AUTOMATIC FILLING TOOLS ON DISPENSERS WITH

ULTRASONIC SENSORS. JARES (Journal of Academic Research and Sciences), 4(1), 55-64. https://doi.org/10.30957/jares.v4i1.690

Table 1. Tool Components

\begin{tabular}{|c|l|l|l|}
\hline No. & Name of Components & \multicolumn{1}{|c|}{ Type } & Jumlah \\
\hline 1. & Sensor Ultrasonik & HC-SR04 & 2 \\
\hline 2. & Mikrokontroler & Arduino Uno ATMega 328 & 1 \\
\hline 3. & Relay & 3 module & 3 \\
\hline 4. & Water pump & HL-881 dan TJ2600 & 2 \\
\hline 5. & Selenoid & - & 1 \\
\hline 6. & LCD & LCD 16x2 Character & 1 \\
\hline 7. & LED & - & 5 \\
\hline
\end{tabular}

\subsection{Tool Design}

The design phase of the water tandon filler and automatic faucet in this dispenser uses block system diagrams and flowchat. For Blog Diagram the water tandon filler and automatic faucet system in the dispenser can be seen in Figure 1. as follow:

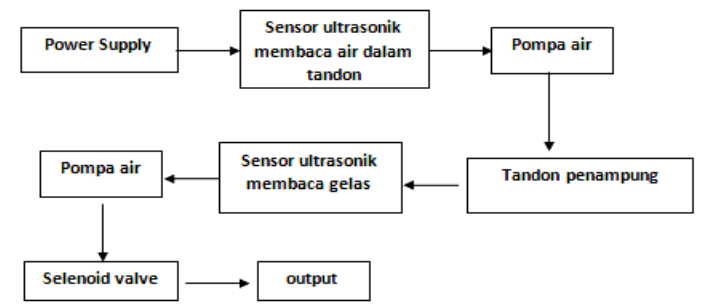

Figure 1. Block system diagram

Power Supply is hardware in the form of a box whose contents are cables to deliver voltage into other hardware. An electronic hardware component that has function as a supplier of electric current by first changing the voltage from AC to DC.

a. Ultrasonic sensors are designed to detect the height or level of a volume of liquid in a tube or tank, the function of this ultrasonic sensor is to detect the amount or volume of water entering the tank, then this sensor is connected to the microcontroller and water pumping machine, when the volume of water inside the tube has reached the full level (high) and detected by the sensor, the sensor will work because the highest water point is set at full or high limits, when the sensor will be read by the microcontroller and will order the water pump to stop rotating, in the sense the microcontroller will decide flow of engine water pump flow.

b. Pump is a tool used to move fluids (fluid) from one place to another, through the media pipe (channel) by adding Energy to the fluid that is removed and continues. The pump operates with the principle of making a pressure difference between the suction section and the discharge part. The difference in pressure results from a mechanism 
JARES, Vol. 4 No. 1 March, 2019; p-ISSN: 2502-826X; e-ISSN: 2503-1163

Copyrights@ Balitar Islamic University, Blitar, Indonesia;

https://ejournal.unisbablitar.ac.id/index.php/jares

Citation: Azzari Aldaf , H., Hartami Santi , I., \& Primasari, Y. (2019). DESIGN OF

TANDON AND AUTOMATIC FILLING TOOLS ON DISPENSERS WITH

ULTRASONIC SENSORS. JARES (Journal of Academic Research and Sciences), 4(1), 55-64. https://doi.org/10.30957/jares.v4i1.690

such as an impeller wheel rotation which makes the suction side almost vacuum. The function of this water pump is to move water from the source (gallon) to the storage reservoir which will then be processed.

c. Water Storage Reservoir serves as a water reservoir in a dispenser that will be processed into hot or cold water. It designed to meet the needs of safe, clean and hygienic water for the community efficiently, because the cleanliness of water cannot be separated from the place to hold water. Water tanks in the dispenser serve as safe water storage for the community.

d. Ultrasonic sensors function to convert physical quantities (sounds) into electrical quantities and vice versa. The workings of this sensor are based on the principle of reflecting a sound wave so that it can be used to interpret the existence (distance) of an object with a certain frequency.

e. Water pump functions to pump and move water which is inside the reservoir to go to selenoid, then the water will go out through selenoid.

$\mathrm{f}$. Selenoid valve is a valve that is driven by electrical energy through a solenoid, has a coil as a driver that serves to move the piston that can be driven by AC or DC currents. This selenoid valve functions as a faucet that will open and close automatically

\subsection{Flowchart of Automatic Drinking Water Dispenser System}

The design of the software (software) used in the design and manufacture of the tool will be present in the overall program flowchart as in Figure 2. As follows:

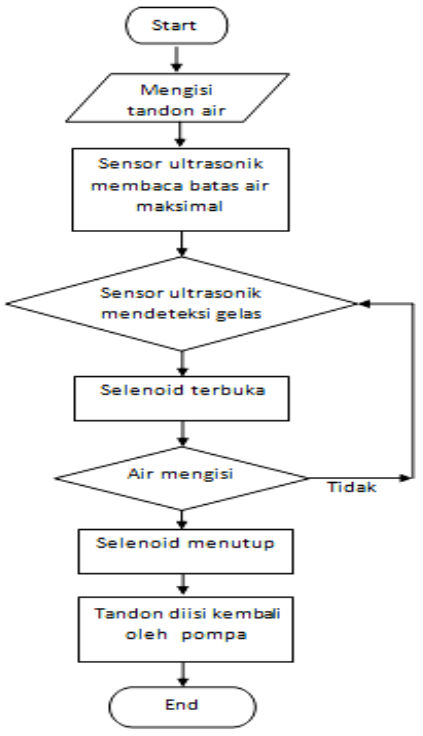

Figure 2. Flowchart system tools 
JARES, Vol. 4 No. 1 March, 2019; p-ISSN: 2502-826X; e-ISSN: 2503-1163

Copyrights@ Balitar Islamic University, Blitar, Indonesia;

https://ejournal.unisbablitar.ac.id/index.php/jares

Citation: Azzari Aldaf , H., Hartami Santi , I., \& Primasari, Y. (2019). DESIGN OF

TANDON AND AUTOMATIC FILLING TOOLS ON DISPENSERS WITH

ULTRASONIC SENSORS. JARES (Journal of Academic Research and Sciences), 4(1), 55-64. https://doi.org/10.30957/jares.v4i1.690

\section{RESULTS AND DISCUSSION}

\subsection{Pump Testing From Gallon to Tandon}

Testing the water pump is done by giving a voltage of $5 \mathrm{v}$. If the output pin 10 on Arduino is worth 1 then it is forwarded to the base of transistor 3 and gets a positive voltage so that the transistor works, the relay also gets a positive voltage so the water pump can turn on.

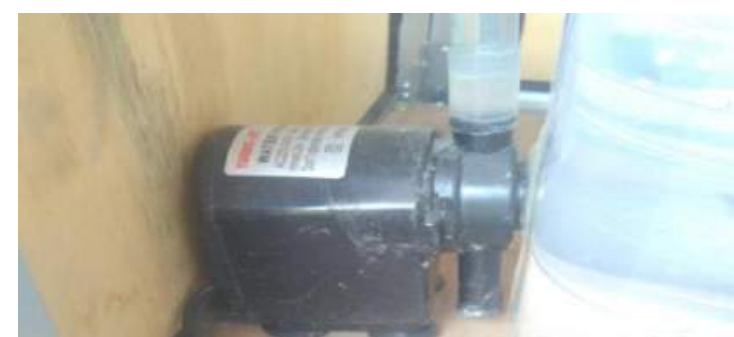

Figure 3. pumping gallon water into the reservoir

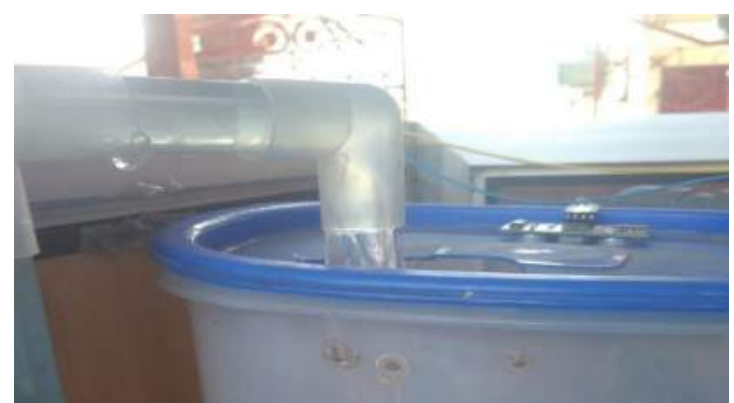

Figure 4. The process of filling water into the tendon

\subsection{Testing of Ultrasonic Sensors on Tubes}

If the maximum water distance is in accordance with the provisions of the $22 \mathrm{~cm}$ ultrasonic sensor on the reservoir, then the output on the water pump pin to the reservoir is 0 , then the base gets a negative voltage which results in the relay getting positive all the water pumps are turned off so that the water filling in the reservoir will stop filling, as in figure 5 below: 
JARES, Vol. 4 No. 1 March, 2019; p-ISSN: 2502-826X; e-ISSN: 2503-1163

Copyrights@ Balitar Islamic University, Blitar, Indonesia;

https://ejournal.unisbablitar.ac.id/index.php/jares

Citation: Azzari Aldaf , H., Hartami Santi , I., \& Primasari, Y. (2019). DESIGN OF

TANDON AND AUTOMATIC FILLING TOOLS ON DISPENSERS WITH

ULTRASONIC SENSORS. JARES (Journal of Academic Research and Sciences), 4(1), 55-64. https://doi.org/10.30957/jares.v4i1.690

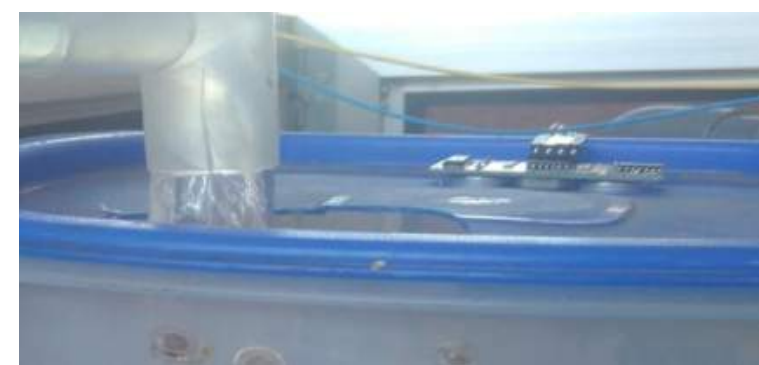

Figure 5. The sensor reads the water level limit

\subsection{Glass Readers Ultrasonic Sensor Testing}

The testing of a glass reader ultrasonic sensor is done by bringing the glass object closer to sensor. If there is an object in front of the ultrasonic sensor it will be read and forwarded to pins 4 and 5 so that it can be processed into Arduino and released through pin 11 which is worth 1 so that the transistor works and the relay gets positive and negative voltage so that the water pump can light up for a certain period. The ultrasonic sensor detects the glass as shown in figure 6 . as follows:

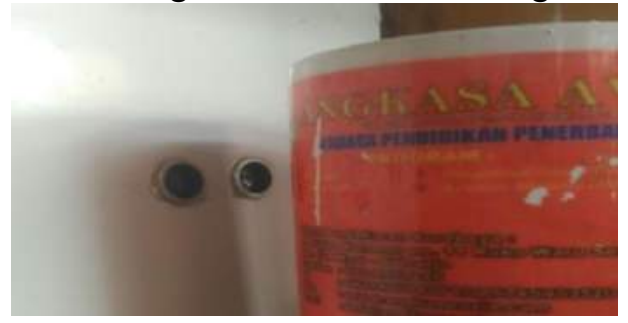

\subsection{Relay Circuit Testing}

Figure 6. Ultrasonic sensor detects glass

Relay circuit testing is carried out by providing a $5 \mathrm{v}$ voltage base 2N2222 transistor, the relay will active and the water pump will turn on. This is because the coil on the relay will be electrified. Thus, the contact will be connected. Diodes function as a safety component of a backflow transistor that may arise due to the active coil relay. The relay circuit test results can be presented as shown in Figure 7, as follow: 
JARES, Vol. 4 No. 1 March, 2019; p-ISSN: 2502-826X; e-ISSN: 2503-1163

Copyrights@ Balitar Islamic University, Blitar, Indonesia;

https://ejournal.unisbablitar.ac.id/index.php/jares

Citation: Azzari Aldaf , H., Hartami Santi , I., \& Primasari, Y. (2019). DESIGN OF

TANDON AND AUTOMATIC FILLING TOOLS ON DISPENSERS WITH

ULTRASONIC SENSORS. JARES (Journal of Academic Research and Sciences), 4(1), 55-64. https://doi.org/10.30957/jares.v4i1.690

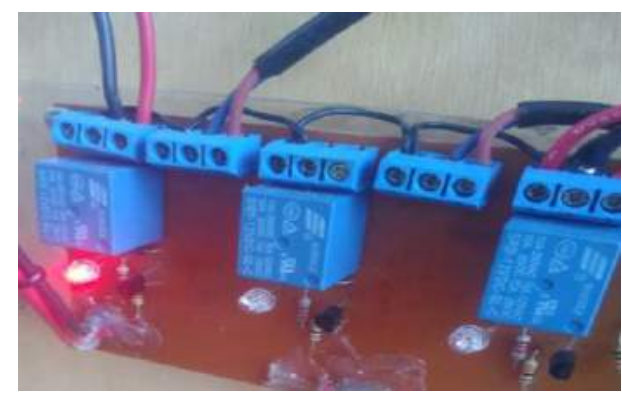

Figure 7. Relays function properly

\subsection{Pump and Selenoid Testing}

The pump output of pin 11 is 1 then base TR1 gets a positive voltage, the transistor will work, the relay gets 2 voltages so that the position of the relay switch changes and will turn on, so the pump and selenoid are on. Testing selenoid by turning on all devices, after that the ultrasonic sensor detects the maximum limit of water on the reservoir, when it is full of water it will stop filling the reservoir. The ultrasonic sensor on the dispenser will detect whether or not there is a glass, after that it will be sent to the microcontroller and the microcontroller will order the relay and proceed to the pump and selenoid valve. Pumps and selenoids here work together because they are arranged in parallel.

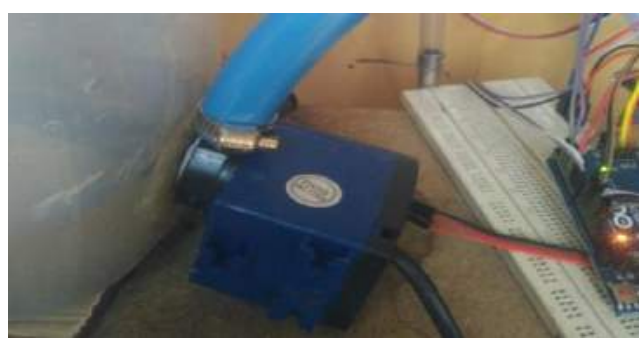

Figure 8. water pump

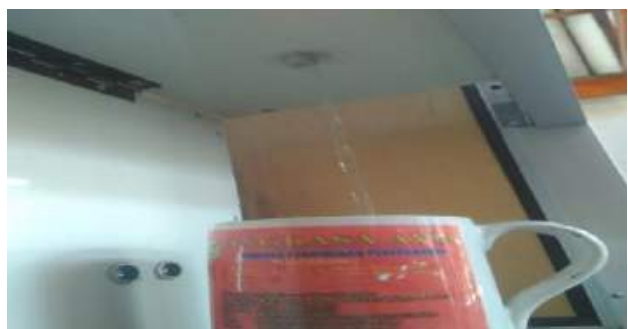

Figure 9. Open selenoid valve 
JARES, Vol. 4 No. 1 March, 2019; p-ISSN: 2502-826X; e-ISSN: 2503-1163

Copyrights@ Balitar Islamic University, Blitar, Indonesia;

https://ejournal.unisbablitar.ac.id/index.php/jares

Citation: Azzari Aldaf , H., Hartami Santi , I., \& Primasari, Y. (2019). DESIGN OF

TANDON AND AUTOMATIC FILLING TOOLS ON DISPENSERS WITH

ULTRASONIC SENSORS. JARES (Journal of Academic Research and Sciences), 4(1), 55-64. https://doi.org/10.30957/jares.v4i1.690

\subsection{Test Results of Tool Design}

The results of testing the design of this tool is a step that is used to determine the extent to which the suitability between the design and the reality on the tool that has been made, whether it is in accordance with the expected or not. The results of testing this tool also to find out whether or not the tool works. The results of the close glass experiment with sensors are presented in the following table:

Table 2. glass filling experiments

\begin{tabular}{|l|l|l|}
\hline \multicolumn{1}{|c|}{ Trial } & \multicolumn{1}{|c|}{$\begin{array}{c}\text { The distance of glass to } \\
\text { sensor }\end{array}$} & \multicolumn{1}{c|}{ Voltage } \\
\hline 1 & $1 \mathrm{~cm}$ & 0 (not legible) \\
\hline 2 & $2 \mathrm{~cm}$ & 1 (egible) \\
\hline 3 & $3 \mathrm{~cm}$ & 1 (egible) \\
\hline 4 & $4 \mathrm{~cm}$ & 1 (egible) \\
\hline 5 & $5 \mathrm{~cm}$ & 0 (not egible) \\
\hline 6 & $6 \mathrm{~cm}$ & 0 (not egible) \\
\hline
\end{tabular}

Table 2 shows that in the first experiment, the distance was measured as far as $1 \mathrm{~cm}$, the result of the first experiment was the distance of unreadable objects so that the voltage was 0 , and could not be forwarded to the microcontroller so it could not be processed. In the second experiment, by adding a testing distance of $2 \mathrm{~cm}$ and the results of the experiments above are legible distances and a value of 1 so that they can be forwarded and processed to the microcontroller. Then the microcontroller flow the current to the relay and the relay opens, causing the water pump and solenoid to open and water to come out. In the third experiment, adding the distance of objects to the sensor is $3 \mathrm{~cm}$, the result of the $3 \mathrm{rd}$ experiment is the distance of $3 \mathrm{~cm}$ still read by the ultrasonic sensor so that the voltage is 1 and can be processed back to the microcontroller. In experiment 4 , add distance to $4 \mathrm{~cm}$, and the result is that ultrasonic sensors can read objects as far as $4 \mathrm{~cm}$ as determined and the voltage is worth 1 . In experiments 5 and 6 by adding a distance of $5 \mathrm{~cm}$ and $6 \mathrm{~cm}$, and the result is the sensor is illegible or no signal $(0)$.

\section{CONCLUSION}

Program applications on the microcontroller can run the system and programs properly so that water tadon and automatic faucet fillers in dispensers using ultrasonic sensors can work well. Ultrasonic sensors can detect glasses at a distance of $2-4 \mathrm{~cm}$. The test results on a glass with a diameter of $8 \mathrm{~cm}$ and a height of $9 \mathrm{~cm}$ will be fully filled by water tadon filler and an automatic faucet in the dispenser for 30 seconds. 
JARES, Vol. 4 No. 1 March, 2019; p-ISSN: 2502-826X; e-ISSN: 2503-1163

Copyrights@ Balitar Islamic University, Blitar, Indonesia;

https://ejournal.unisbablitar.ac.id/index.php/jares

Citation: Azzari Aldaf , H., Hartami Santi , I., \& Primasari, Y. (2019). DESIGN OF

TANDON AND AUTOMATIC FILLING TOOLS ON DISPENSERS WITH

ULTRASONIC SENSORS. JARES (Journal of Academic Research and Sciences), 4(1), 55-64. https://doi.org/10.30957/jares.v4i1.690

\section{SUGGESTIONS}

The flow of water from the faucet will flow more profusely when the water pressure in the selenoid is greater, so it is necessary to try to use a solenoid with a large output hole.

\section{DAFTAR PUSTAKA}

[1] Adhitya, V. N, Hafidudin. Sarwoko, M. (2014). merancang sebuah kran otomatis menggunakan sensor ultrasonik

[2] Dwisnita Kusbintarti (2014) Dispenser Pengisi gelas Otomatis Menggunakan Sensor Ultrasonik dan Sensor Posisi Resitif , Fakultas Teknik Universitas Brawijaya

[3] Elektrokontrol (2011) Pengisian Tangki (tandon) air otomatis menggunakan ATmega8535

[4] Gamis Pindhika Darma, Wisnu Wendanto (2015) Rancang bangun dispenser otomatis berbasis mikrokontroler Atmega16, STMIK AUB Surakarta

[5] Gusrizam Danel, Wildian (2012), Otomatisasi Keran Dispenser Berbasis Mikrokontroler AT89S52 menggunakan Sensor Fotodioda dan SensorUltrasonik Ping, Jurusan Fisika FMIPA Universitas Andalas

[6] Imran Oktariawan, Martinusdan Sugiyanto (2014) Pembuatan Sistem Otomasi Dispenser Menggunakan Mikrokontroler Arduino Mega 2560, Fakultas Teknik Universitas Lampung

[7] Subandi (2014), memanfaatkan sensor pada rangkaian elektronika

[8] Gusrizam D, Wildian, 2012, Otomatisasi Keran Dispenser Berbasis Mikrokontroler AT 89 S52 Menggunakan Sensor Fotodioda dan Sensor Ultrasonik Ping, Skripsi Universitas Andalas Padang

[9] Sandi, SB. 2016. Memperbaiki Dispenser Air Panas dan Dingin yang Rusak dengan Mengacu Pada Kerusakan Bagian yang Sering Terjadi. 